\title{
Discriminating the Validity of Speech Mechanism Screening Test for Children for Children with Speech Sound Disorders: A ROC Curve Analysis
}

\author{
Jaeock Kim \\ Division of Speech Pathology Education, Graduate School of Education, Kangnam University, Korea
}

Correspondence: Jaeock Kim, $\mathrm{PhD}$

Division of Speech Pathology Education, Graduate School of Education, Kangnam University, 40 Gangnam-ro, Giheung-gu, Yongin 16979, Korea Tel: $+82-31-280-3221$

Fax: +82-31-280-3479

E-mail: jaeock@gmail.com

Received: October 20, 2019

Revised: November 21, 2019

Accepted: December 4, 2019

This research was supported by 2016 Kangnam University Research Grants (2nd) and was partly presented at the 2018 American Speech-LanguageHearing Association (ASHA) Convention held on November 16, 2018.

\begin{abstract}
Objectives: The purpose of the study was to examine whether the Speech Mechanism Screening Test for Children (SMST-C) can discriminate between children with speech sound disorders (SSD) and children with typical development (TD). Methods: Twenty-four children with SSD and 20 with TD from 3 to 6 years of age participated. Each group included 13 boys and 7 girls (mean age, 4.75 years). They were assessed using the SMST-C, which consists of a total score derived from structure/function, phonation/voice/articulation, and diadochokinesis (DDK) scores and DDK rates. DDK rates are alternative motion rates (AMRs) of $/ \mathrm{p}^{\mathrm{h}} \Lambda /, / \mathrm{t}^{\mathrm{h}} \Lambda /, / \mathrm{k}^{\mathrm{h}} \Lambda /, / \mathrm{L}_{\mathrm{N}} /$, and $/ \mathrm{k} \Lambda \mathrm{n} /$ and sequential motion rates (SMR) of $/ \mathrm{p}^{\mathrm{h}} \Lambda \mathrm{t}^{\mathrm{h}} \Lambda \mathrm{k}^{\mathrm{h}} \Lambda /$. These variables were compared between the two groups. The cutoff value of each variable to discriminate between two groups was determined by receiver operating characteristic (ROC) analyses. Results: The SMST-C scores of the SSD group were significantly lower in total, articulation, and DDK when compared with children with the TD. DDK rates of $/ p^{h} \Lambda /, / k^{h} \Lambda$, $/ k \wedge \eta /$, and $/ p^{h} \wedge t^{h} \wedge k^{h} \Lambda /$ were significantly slower in the SSD group. However, no differences were found in structure/function and voice scores. ROC analyses showed DDK score (area under curve $[A U C]=.879$ ), phonation/voice/articulation score (AUC $=.864$ ), and total score (AUC $=.846$ ) had higher discrimination accuracy for classifying SSD with high sensitivity and specificity. Conclusion: This study provided quantified data regarding the validity of the SMST-C in children with SSD. The SMST-C is helpful to screen the speech mechanisms of children with SSD. Therefore, the SMST-C can be used in clinics to screen children with pathological speech mechanisms.
\end{abstract}

Keywords: Speech Mechanism Screening Test for Children, Speech sound disorder, Diadochokinetic rate 말소리장애(speech sound disorder, SSD)는 언어적 그리고 운동 적 측면의 결함으로 인해 해당 연령에 적합한 말소리를 정확하게 산출하는데 어려움을 보이는 말장애이다(Farquharson, 2015; Grigos, 2016; Vick et al., 2014; Waring \& Knight, 2013). 말소리장애는 원인이 분명한 경우(예: 청각장애, 구개파열, 뇌병변장애 등)와 원인 이 분명하지 않은 경우로 구분된다(Kim \& Shin, 2015). 선행연구에 따르면 5 세까지 아동의 말소리장애 출현율은 $14 \%-25 \%$ 라고 한다 (Jessup, Ward, Cahill, \& Keating, 2008; McLeod \& Harrison, 2009). 이 중에서 원인을 모르는 말소리장애의 출현율(prevalence)은 5-7
세 아동의 $2 \%-25 \%$ (Law, Boyle, Harris, Harkness, \& Nye, 2000), 학령기 아동의 약 $1.06 \%$ (McKinnon, McLeod, \& Reilly, 2007), 3-11세 아동의 경우 약 7.5\% (as cited in Kim \& Shin, 2015)이다. 국 내 보고에서도 영유아기부터 청소년기의 의사소통장애 대상자의 약 $44.1 \%$ 가 말소리 산출의 문제가 있고, 이 중 약 $26 \%$ 가 다른 장애 가 없는 순수 말소리장애이며, 이들은 전체 의사소통장애의 약 $11.6 \%$ 를 차지한다고 한다(Kim, Kim, Ha, \& Ha, 2014). 말소리장애 아동 중에서도 순수 말소리장애의 비율이 약 $42 \%$ 에 해당한다는 연구도 있다(Ko, Seo, Oh, \& Kim, 2017). 
순수 말소리장애는 언어·인지처리의 문제, 청지각 처리의 문제, 사회심리적 문제, 말운동 통제능력의 문제, 음운인식이나 음운처리 의 문제 등 다양한 변인들에 의해 발생할 수 있다. 이에 말소리장애 에 내재되어 있는 직접적 원인을 찾는 것은 쉽지 않다(Farquharson, 2015; Kim \& Shin, 2015).

모든 말산출은 개념형성 및 부호화(coding) 과정의 언어적 측면 그리고 말운동계획, 말운동프로그래밍 및 말운동실행과 같은 운 동적 측면이 단계적으로 함께 작용하므로 이들을 따로 분리하여 살펴보는 것이 어렵다. 또한 정상적인 말소리를 산출하기 위해서는 호흡, 발성, 조음, 공명 등의 말산출 기전에 관여하는 하부체계의 구 조와 기능, 그리고 이들 간의 협응 능력이 요구된다. 선행연구에 의 하면 말소리장애 아동은 정상 발달 아동(children with typical development, TD)에 비해 구강운동, 소근육운동, 대근육운동 능력 이 감소되어 있다고 한다(Cermak, Ward, \& Ward, 1986; Farquharson, 2015, Lewis et al., 2011; Newmeyer et al., 2007; Peter \& Stoel-Gammon, 2008; Redle et al., 2015). 즉 원인을 모르는 순수 말 소리장애를 평가할 때에는 음운 능력을 포함한 언어적 측면뿐 아 니라 말산출에 관여하는 하부체계의 구조나 감각-운동적 측면, 그 리고 하부체계들 간의 협응 능력을 살펴볼 필요가 있다(Shriberg, Gruber, \& Kwiatkowski, 1994).

청각장애, 구개파열, 뇌병변장애 등과 같이 기질적으로 명확한 원인을 동반한 말소리장애의 경우에는 조기에 중재가 이루어질 수 있다. 그러나 원인이 불분명한 순수 말소리장애는 평가와 중재가 조기에 이루어지지 못하는 경우가 많아 학령기까지 말소리장애가 지속됨으로써 학습 능력과 교우관계에 영향을 미친다(Kim \& Shin, 2015). 아동의 순수 말소리장애가 학령기나 성인기까지 지속되지 않도록 하기 위해서는 조기에 이를 선별 평가하는 것이 매우 중요 하다. 또한 선별검사를 통해 말소리장애가 있다고 판단되는 경우는 심화검사를 통해 보다 정확하게 진단해야 한다.

말소리장애 유무를 선별하기 위해 비공식검사와 공식검사가 사 용될 수 있는데, 비공식검사는 아동이 해당하는 연령의 조음음운 발달에서 완전습득연령에 해당하는 음소들의 오조음 여부를 평가 한다. 공식검사로는 Kim과 Yoo (2014)의 문장 따라말하기 과제 (sentence repetition task)로 구성된 “놀이동산 따라말하기 선별검 사”가 있다. 이러한 말소리장애 선별을 위한 비공식검사와 공식검 사는 주로 음운인식과 음운산출 능력을 위주로 살펴보는 것으로, 말산출 기전에 관여하는 하부체계의 구조나 기능 또는 말운동 능 력을 평가하지는 않는다. 앞에서도 언급한 바와 같이 정확한 원인 을 파악하기 어려운 순수 말소리장애의 경우 단순히 음운 능력과 관련된 측면만 평가할 것이 아니라 말소리산출 하부체계의 운동적
특성 또한 살펴보아야한다.

국내에서 아동을 대상으로 의사소통장애 아동을 평가하기 위 해 말산출 기전에 관여하는 하부체계의 구조와 기능 및 말운동의 이상 유무를 선별하는 아동용 조음기관 구조.기능 선별검사(Speech Mechanism Screening Test for Children, SMST-C)가 최근 개발되 었다. 그리고 이를 3-12세 아동 235명을 대상으로 표준화를 실시하 였다(Kim, Shin, \& Song, 2018).

SMST-C는 '조음기관 구조·기능, '발성·음성·조음선별' , 조음교 대운동'의 세 하위영역의 각 점수를 합한 총점수와 최대발성시간 (maximum phonation time, MPT), 말속도, 및 조음교대운동속도 (diadochokinetic rate, DDK rate)로 구성되어 있다. SMST-C 하위 영역의 점수와 수치는 아동의 말산출 기전에 관여하는 기관들의 구조와 기능 및 말운동 능력을 반영함으로써 정상 발달 아동과 말 산출 기전의 이상이 있는 아동을 변별하는데 사용될 수 있다.

중증도가 경하거나중간 정도인 뇌성마비 아동을 대상으로 SMST$\mathrm{C}$ 를 이용하여 정상 발달 아동의 말산출 하부체계의 구조와 기능 및 말운동 능력을 비교한 연구에 따르면, SMST-C를 구성하는 모 든 하위영역, 즉 조음기관의 구조와 기능, 발성이나 음성적 특성, 그 리고 조음음운적 특성 및 $\mathrm{DDK}$ 와 같은 말운동 능력 모두에서 뇌성 마비 아동이 정상 발달 아동에 비해 현저하게 낮은 점수를 보였다. 즉 SMST-C을 통해 뇌성마비 아동을 유의하게 변별할 수 있음을 보여주었다(Kim \& Lee, 2018).

이에 본 연구에서는 SMST-C가 조음기관의 구조나 기질적인 부 분의 문제가 없고 원인이 명확하지 않은 순수 말소리장애(이하 말 소리장애) 아동과 정상 발달 과정에 있는 일반아동을 변별할 수 있 는지를 살펴보고자 하였다. 이를 위해 두 집단의 MPT와 말속도를 제외한 SMST-C의 총점수와 세 하위영역의 점수, 그리고 DDK 속 도를 비교하였다. 또한 수신자 조작 특성(receiver operating characteristics, ROC) 곡선 분석을 통해 SMST-C를 구성하는 하위영역 들이 두 집단을 얼마나 효과적으로 변별할 수 있는지를 살펴보고 자하였다.

\section{연구방법}

\section{연구대상}

서울 또는 경기 지역에 거주하는 만 3-6세 말소리장애로 진단받 은 아동 20 명과 일반아동 20 명을 대상으로 하였다. 본 연구에 참여 한 모든 아동은 주양육자 또는 교육기관(어린이집, 유치원, 학교)의 담임교사에 의해 신체적, 감각적, 정서적, 행동적, 인지적 및 언어적 으로 문제가 없다고 보고되었고, 수용 및 표현어휘력검사(Recep- 
tive and Expressive Vocabulary Test, REVT; Kim, Hong, Kim, Jang, \& Lee, 2009)의 수용어휘력 점수가 생활연령을 기준으로 -1 SD 이 상의 정상 범주에 속하는 아동으로 선정하였다. 다문화가정의 아 동이나 치아를 교정 중인 아동은 제외하였다. 말소리장애 아동은 (1) 언어치료기관에서 언어재활사에 의해 말소리장애로 진단받았 거나 주양육자 또는 담임교사에 의해 말소리 발달에 문제가 있다 고 보고되었으며, (2) 우리말 조음·음운평가(Urimal Test of Articulation and Phonology, U-TAP; Kim \& Shin, 2004)의 단어수준 자 음정확도가 생활연령을 기준으로 -2 SD 이하에 속하고, (3) 중복장 애(예: 자폐스펙트럼장애, 청각장애, 구개파열, 뇌병변장애 등)로 진 단받지 않은 아동을 대상으로 하였다. 일반아동은 U-TAP의 단어 수준 자음정확도가 생활연령을 기준으로 -1 SD 이상의 정상 범주 에 속하는 아동으로 하였다.

두 집단의 성별과 연령을 일치시켰고, 각 집단별로 남아가 13 명, 여아가 7명이었으며, 두 집단 모두 평균 연령은 4.75세(SD $=1.02)$ 였 다. 각 집단별로 3 세는 여아가 2 명, 4 세는 남아가 6 명과 여아가 1 명, 5 세는 남아가 3 명과 여아가 2 명, 6 세는 남아가 4 명과 여아가 2명, 7 세, 8 세, 10 세, 12 세가 각 남아가 1 명으로 구성되었다.

\section{검사도구}

본 연구에서는 말소리장애 아동과 일반아동의 말산출 하부체계 인 조음기관의 구조와 기능을 비교하기 위해 선행연구(Kim \& Kim, 2016; Kim et al., 2018)에서 제시한 SMST-C를 이용하였다. SMST$\mathrm{C}$ 를 구성하는 각 하위영역(조음기관 구조.기능', '발성·음성·조음 선별', ‘조음교대운동')의 점수와 이들의 합산으로 산출되는 총점 수, 그리고 DDK 속도를 산출하였다. SMST-C의 하위영역 중 '발 성·음성·조음선별'에서 발성에 해당하는 MPT와 말속도를 평가하 는 항목은 제외하였다. 본 연구에서는 신체의 이상이 없는 아동만 을 대상으로 하여 호흡과 후두 간의 협응을 살펴보는 MPT는 포함 시키지 않았고, 학령전기에 해당하는 아동만을 대상으로 하였기 때문에 말속도 측정을 위한 읽기평가를 실시하지 못하였으므로 말 속도는 포함시키지 않았다.

SMST-C를 구성하는 세 하위영역의 각 항목은 3 점 척도 $(0$ 점 = 심각한 비정상, 1 점 $=$ 약간 비정상, 2 점 = 정상 $)$ 로 구성된다. '조음기 관 구조·기능은 얼굴, 입술, 혀, 턱·치아, 경구개·연구개, 호흡기관, 인두로 구성된 7 개 영역의 외관상 관찰되는 구조와 비구어 운동과 제로 기능의 이상 여부를 평가한다. 이 중에서 ‘조음기관 구조'는 14 항목으로 0-28점이며, '조음기관 기능'은 16항목으로 0-32점으로 총 0-60점이 가능하다. '발성·음성·조음선별'에서 총점수에 포함 되는 영역은 ‘음성’과 ‘조음선별’이며, ‘음성’은 자발화, 모음연장발
성 및 단어나 문단읽기의 말운동 과제를 실시할 때 음도(pitch), 음 강(음의 크기, loudness) 및 음질(voice quality)을 평가하는 3항목 으로 구성되며, 각 항목당 0-2점으로 0-6점이 산출된다. '조음선별' 은 학령전기 아동을 위해서는 13 개 단어로 구성된 그림카드에서 각 단어 어두초성의 자음오류 유무를 선별하고, 학령기 아동에서 는 읽기카드로 제시된 문장을 읽을 때/ㄹ/,/ / / / / ㅈ/의 조음오류 유 무를 선별한다. 그림카드나 읽기카드에서 제시된 전체 음소 중 한 음소라도 문제가 있으면 0점(대치/생략) 또는 1점(왜곡)을 부여하 여 총 0-2점이 산출된다. 단, 자음습득연령(Kim \& Pae, 2005; Kim, 1995)에 따라 해당 생활연령에서 산출되지 못하는 자음의 오류가 발생한 경우는 정상으로 간주한다. 본 연구에서는 학령전기 아동 만을 대상으로 하였기에 '조음선별' 검사를 위해 그림카드만을 이 용하였다. '발성·음성·조음선별'에서 산출될 수 있는 점수는 0-8점 이지만 총점수에 비해 점수의 비중이 낮아 2 배의 가중치를 부여함 으로써 0-16점이 된다. '조음교대운동'은 5개 일음절과/퍼터커/를 5 초간 최대한 빠르고 정확하게 반복하는 동안 ‘조음규칙성’과 ‘조음 정확성'을 평가하며 0-24점이 산출될 수 있다. 따라서 세 하위영역 의 점수들을 합한 총점수는 0-100점이 가능하고, 점수가 높을수록 조음기관의 구조와 기능 및 말운동 능력이 정상임을 의미한다.

또한 $\mathrm{DDK}$ 속도는 ‘조음교대운동’과 함께 측정하는데, 이를 측정 하기 위해 사용된 일음절은 일반적으로 많이 사용되는 파열음과 각 조음위치에서 가장 편안하게 조음할 수 있는 중성모음으로 이루 어졌다. 이에 일음절은 조음위치에 따라 양순음 /퍼/, 치조음 /터/, 연구개음 /커/와 설소대의 구조와 기능을 평가하기 위한 치경설측 음/러/로 구성된다. 그리고 구강음과 비강음을 연속적으로 빠르게 산출함으로써 연구개와 목젖의 움직임이 정상인지를 살펴보기 위 해 구강음과 비강음이 결합된/겅/을 추가하여 총 5 개로 구성되었다.

$\mathrm{DDK}$ 속도는 앞에서 설명한 5 개의 일음절을 각각 반복하여 산출 하는 교대운동속도(alternating motion rate, AMR)와/퍼터커/의 3 음절을 일련으로 산출하는 일련운동속도(sequential motion rate, $\mathrm{SMR}$ )로 구분된다. SMST-C의 구성요소와 점수체계는 Appendix 1에 제시하였다.

\section{자료수집}

아동이 재학 중인 교육기관 또는 집의 조용한 공간에서 임상경 력이 5 년 이상인 2 급 언어재활사 1 명이 아동과 편안한 자세로 일대 일로 마주보고 앉은 후 아동에게 본 검사에 대해 간단하게 설명하 고 진행하였다. 본 검사의 하위영역인 '조음기관 구조.기능'은 이비 인후과용 구강경, 펜라이트 및 설압자를 이용하여 얼굴, 입술, 혀, 턱·치아, 경구개·연구개, 호흡기관, 인두의 7 개 영역을 항목별로 평 
가하고 해당 점수를 기록하였다. '발성·음성·조음선별'을 평가하기 위해 “나는 OOO어린이집/유치원 OOO반 OOO입니다”의 자발화 및 편안한 음도와음강으로/아/ 모음을 최대한 길게 연장 발성하는 MPT 과제를 수행하였다. 다만 앞에서 언급한 바와 같이 본 연구에 서는 MPT를 분석에 포함시키지는 않았고, 음성평가를 위해 실시 하였다. 그리고 그림카드로 '조음선별'을 실시하면서 음성과 조음 선별의 각 항목에 해당하는 점수를 기록하였다. '조음교대운동'과 $\mathrm{DDK}$ 속도는 5 개 일음절과 /퍼터커/를 아동이 최대한 정확하고 빠 르게 5 초간 반복하여 조음하는 동안 '조음규칙성'과 '조음정확성' 에 해당하는 점수를 기록하였고, 이를 1 초 동안에 조음한 횟수로 계산하여 $\mathrm{DDK}$ 속도를 측정하였다. 아동이 정확하게 수행하지 못 하거나 말소리가 부정확하다고 판단될 경우에는 과제수행을 중지 하고 검사자가 1-2회 시범을 보였고, 아동이 충분한 연습을 한 후 수행하게 하였다. AMR과 SMR은 각 음절별로 2회씩 반복하여 산 출한 것의 평균값을 계산하였다. '발성·음성·조음선별'과 '조음교 대운동'을 실시하는 동안 산출된 음성은 디지털녹음기(PCM-D50; SONY, Tokyo, Japan)로 녹음하였다.

\section{자료분석}

아동의 DDK 속도를 녹음한 음성파일은 Cool Edit Pro v2.1 (Syntrillium, Scottsdale, AZ, USA)을 통해 1 명의 아동당 12 개(5개 일음 절과 /퍼터커/의 2 회 반복)의 음성파형으로 분리하여 저장하였다. 각 음성파형은 시작 지점부터 끝 지점까지 5 초간 산출된 음절(에너 지가 증가한 부분)의 개수를 세어 이를 5 로 나누어 1 초당 산출한 음절수로 계산하였다. 5 초간 반복이 어려운 경우에는 수집된 최대 의 길이를 사용하여 분석하였다.

\section{신뢰도}

신뢰도 검정을 위해 주양육자나 담임교사의 허락 하에 전체 아 동의 약 $15 \%$ 에 해당하는 7 명의 검사 과정과 음성파일을 비디오와 녹음기를 사용하여 녹음하였다. 녹음한 자료를 임상경력이 10년 이상인 언어재활사가 재평가하여 Spearman rho 상관분석을 실시 한 결과, 총점수와 DDK 속도의 평가자 내 신뢰도는 각. 980 ( $p<.001)$ 과 1.000 ( $p<.001)$ 이었고, 평가자 간 신뢰도는 .932 ( $p<.001)$ 와 1.000 ( $p$ <.001)로 모두 유의하게 높았다.

\section{통계처리}

두 집단(말소리장애 아동과 일반아동) 간 SMST-C의 총점수와 총점수를 이루는 세 하위영역 점수의 차이는 독립표본 $t$-검정으로 비교하였다. 두 집단과 5 개 일음절에 따른 AMR 간 차이는 집단을
개체 간 요인으로 하고 일음절을 개체 내 요인으로 하는 이원혼합 분산분석(two-way mixed ANOVA)으로 비교하였고, 일음절 간에 유의한 차이가 있는 경우는 주효과 분석을 실시하였다. 두 집단 간 $\mathrm{SMR}$ 의 차이는 독립표본 $t$-검정으로 비교하였다. 또한 모든 변수의 말소리장애 유무 변별 가능성을 알아보기 위해 ROC 곡선 분석을 통해 총점수, 각 하위영역의 점수, $\mathrm{AMR}$ 및 SMR의 곡선 아래 영역 (area under curve, AUC)을 산정하였으며, Youden의 index를 사용 하여 각 측정치의 민감도와 특이도 및 말소리장애를 변별하는 절 단점(cutoff value)을 분석하였다. 독립표본 $t$-검정과 이원혼합분산 분석은 IBM SPSS Statistics version 24.0 프로그램(IBM Co., Armonk, NY, USA)을 사용하였고, ROC 곡선 분석은 MedCalc 통계 소프트웨어 버전 19.1 프로그램(MedCalc Software, Ostend, Belgium)으로 분석하였다.

\section{연구결과}

\section{집단 간 SMST-C 점수 비교}

$\mathrm{ROC}$ 곡선 분석에 앞서 말소리장애 아동과 일반아동 간의 SMSTC 점수(총점수, ‘조음기관 구조.기능, ‘발성·음성·조음선별' 및 ‘조 음교대운동')를 비교한 결과는 Table 1과 같다. 총점수는 말소리장 애 아동의 평균이 88.45 점으로 일반아동의 96.40 점에 비해 유의하 게 낮았다 $(t=-4.736, p<.001)$. 총점수를 구성하는 하위영역 중 '발 성·음성·조음선별' $(t=-5.204, p<.001)$ 과 '조음교대운동' $(t=-5.634$, $p<.001)$ 는 말소리장애 아동이 일반아동에 비해 유의하게 낮은 점 수를 보였으나 '조음기관 구조.기능'은 두 집단 간에 유의한 차이가 없었다. 특히 ‘발성·음성·조음선별’에서 ‘음성’은 두 아동 집단 간에 유의한 차이가 없는 반면, '조음선별'은 말소리장애 아동의 평균이 0.60점, 일반아동이 3.70점으로 말소리장애 아동이 유의하게 낮은 점수를 보였다. '조음선별'에서 낮은 점수를 보인 경우를 살펴보면, 말소리장애 아동은 20 명 중 15 명이 대치나 생략의 형태로 조음 오 류를 보였고, 2 명이 왜곡을 보였으며, 3 명은 정상 조음을 하였다. 또 한 일반아동에서도 3명이 왜곡을 보였다. '조음교대운동'에서 '조음 규칙성'의 평균은 말소리장애 아동이 10.40점, 일반아동이 11.90점 이었고, '조음정확성'의 평균도 말소리장애 아동이 9.70점, 일반아 동은 11.95점으로 '조음규칙성' $(t=-3.887, p=.001)$ 과 '조음정확성' $(t=-4.869, p<.001)$ 모두 말소리장애 아동이 유의하게 낮았다.

'조음교대운동'을 좀 더 면밀히 살펴본 결과, 한 음절 이상 규칙적 으로 조음하지 않은 경우는 말소리장애 아동이 13 명, 일반아동이 2 명이었고, 한 음절 이상 정확하게 조음하지 않은 경우도 말소리장 애 아동이 15 명인 반면, 일반아동은 1 명으로 나타나 말소리장애 
Table 1. Total, structure/function, phonation/voice/articulation, and DDK scores of SMST-C between SSD and TD groups

\begin{tabular}{|c|c|c|c|c|}
\hline Parameter (score range) & SSD group $(N=20)$ & TD group $(\mathrm{N}=20)$ & $t$ & $p$-value \\
\hline Total (0-100) & $88.45 \pm 4.07$ & $96.40 \pm 3.87$ & -4.736 & $<.001$ \\
\hline Structure/function (0-60) & $56.45 \pm 2.31$ & $55.85 \pm 3.38$ & .656 & .516 \\
\hline Structure (0-28) & $25.60 \pm 1.79$ & $25.45 \pm 2.05$ & .247 & .806 \\
\hline Function (0-32) & $30.85 \pm 1.39$ & $30.40 \pm 1.82$ & .880 & .384 \\
\hline Phonation/voice/articulation (0-16) & $11.90 \pm 1.89$ & $14.70 \pm 1.49$ & -5.204 & $<.001$ \\
\hline Voice (0-12) & $11.30 \pm 1.17$ & $11.00 \pm 1.38$ & .742 & .463 \\
\hline Articulation (0-4) & $0.60 \pm 1.47$ & $3.70 \pm 0.73$ & -8.462 & $<.001$ \\
\hline DDK (0-24) & $20.10 \pm 2.94$ & $23.85 \pm 0.49$ & -5.634 & $<.001$ \\
\hline Articulation regularity (0-12) & $10.40 \pm 1.70$ & $11.90 \pm 0.23$ & -3.887 & .001 \\
\hline Articulation accuracy (0-12) & $9.70 \pm 2.06$ & $11.95 \pm 0.22$ & -4.869 & $<.001$ \\
\hline
\end{tabular}

Values are presented as mean \pm SD.

DKK= diadochokinesis; SMST-C=Speech Mechanism Screening Test for Children; SSD= speech sound disorder; TD= typical development.

Table 2. AMR and SMR between SSD and TD groups

\begin{tabular}{lcc}
\hline Parameter & SSD group $(\mathrm{N}=20)$ & TD group $(\mathrm{N}=20)$ \\
\hline AMR $(\mathrm{syl} / \mathrm{sec})$ & & \\
$/ \mathrm{p}^{\mathrm{h}} \Lambda /$ & $3.43 \pm 0.93$ & $4.03 \pm 0.67$ \\
$/ \mathrm{t}^{\mathrm{h}} \Lambda /$ & $3.66 \pm 0.95$ & $4.08 \pm 0.67$ \\
$/ \mathrm{k}^{\mathrm{h}} \Lambda /$ & $3.31 \pm 1.01$ & $3.93 \pm 0.74$ \\
$/ \mathrm{l} \Lambda /$ & $3.51 \pm 0.63$ & $3.79 \pm 0.63$ \\
$/ \mathrm{k} \Lambda \mathrm{y} /$ & $3.15 \pm 0.70$ & $3.52 \pm 0.71$ \\
$\mathrm{SMR}(\mathrm{syl} / \mathrm{sec})$ & & \\
$/ \mathrm{p}^{\mathrm{h}} \Lambda \mathrm{t}^{\mathrm{h}} \Lambda \mathrm{k}^{\mathrm{h}} \Lambda /$ & $1.24 \pm 0.35$ & $1.45 \pm 0.32$ \\
\hline
\end{tabular}

Values are presented as mean $\pm \mathrm{SD}$.

$A M R=$ alternative motion rate; $S M R=$ sequential motion rate; $S S D=$ speech sound disorder; TD= typical development.

아동이 $\mathrm{DDK}$ 수행에서 규칙적이지 않고 정확하지 않은 경우가 많 았다.

\section{집단 및 일음절에 따른 $\mathrm{AMR}$ 및 집단 간 SMR 비교}

각 일음절의 $\mathrm{AMR}$ 과 $\mathrm{SMR}$ 의 평균과 표준편차는 Table 2와 같다. 집단(2개)과 일음절(5개)에 따른 $\mathrm{AMR}$ 의 차이를 이원혼합분산분 석으로 비교한 결과, 구형성 가정이 이루어지지 않아 GreenhouseGeisser 검정을 실시하였다. 이에 따르면, 집단과 일음절 간 상호작 용은 없었고, 집단에 따른 차이 $(F=4.386, p=.043)$ 와 일음절에 따 른 유의한 차이가 나타났다 $(F=9.986, p<.001)$. 이에 실시한 일음절 간 주효과 분석 결과, /퍼/-/겅/( $p=.005)$, /터/-/겅/( $p<.001)$, /커/-/겅/ ( $p=.030)$, /러/-/겅/( $p=.005), /$ 터/-/커/( $p=.001)$ 간에 유의한 차이 가 있었고, 다른 일음절들 간에는 통계적으로 유의한 차이가 없었 다. 각 집단별로 구분하여 일음절 간 주효과 분석을 실시한 결과, 말 소리장애 아동은 /터/-/겅/( $p=.022), /$ 터/-/커/( $p=.007)$ 간에만 유 의한 차이가 나타난 반면, 일반아동은 /퍼/-/겅/( $p=.004)$, /터/-/겅/

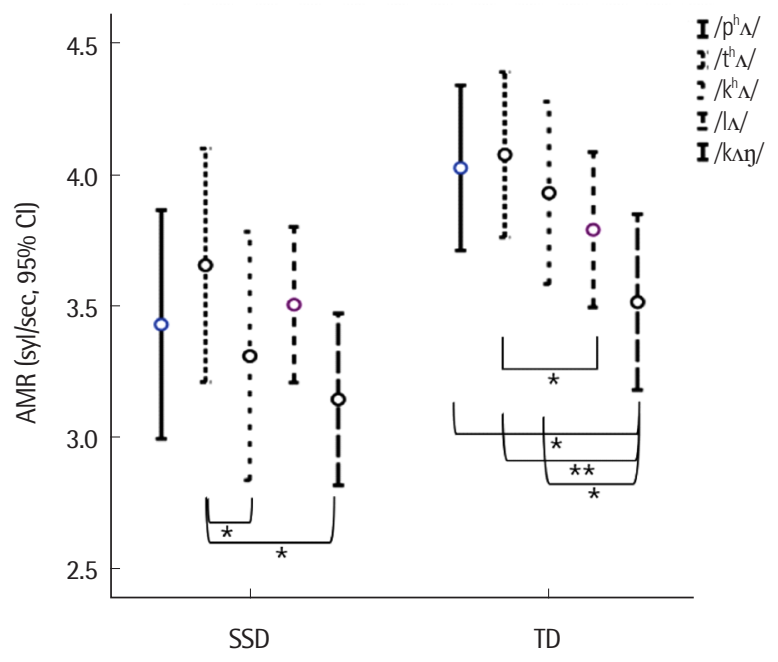

Figure 1. AMR of 5 syllables by group. Error bar represents the standard deviation of the data.

$\mathrm{AMR}=$ alternative motion rate; $\mathrm{SSD}=$ speech sound disorder; $\mathrm{TD}=$ typical development.

${ }^{*} p<.05,{ }^{* *} p<.001$.

( $p<.001), /$ 커/-/겅/( $p=.029), /$ 터/-/러/( $p=.013)$ 간에 유의한 차이를 보였다(Figure 1).

두 집단 간 $\mathrm{SMR}$ 을 비교하였을 때 집단에 따라 통계적으로 유의 한 차이는 없었으나 말소리장애 아동의 평균(1.24)이 일반아동의 평균(1.45)에 비해 낮은 값을 보였다.

\section{SMST-C 점수 및 DDK 속도의 말소리장애 변별 가능성}

SMST-C 점수와 DDK 속도가 말소리장애 아동과 일반아동을 변별할 수 있는지를 알아보기 위해 실시한 ROC 곡선 분석 결과는 Table 3, Figures 2와 3에 제시되어 있다. SMST-C 총점수, '조음기관 구조·기능' '발성·음성·조음선별', ‘조음교대운동' 점수들의 AUC 
Table 3. Diagnostic ability of SMST-C scores and DDK rates

\begin{tabular}{|c|c|c|c|c|c|c|c|}
\hline Parameter & AUC & $95 \% \mathrm{Cl}$ & $z$ & $p$-value & Cut-off value & Sensitivity (\%) & Specificity (\%) \\
\hline Total score & .846 & $.697-.941$ & 5.358 & $<.001$ & 93 & 95 & 70 \\
\hline Structure/function & .506 & $.344-668$ & .066 & .947 & 55 & 60 & 25 \\
\hline Phonation/voice/articulation & .864 & $.718-.951$ & 6.225 & $<.001$ & 12 & 85 & 85 \\
\hline DDK & .879 & $.737-.960$ & 7.304 & $<.001$ & 23 & 80 & 90 \\
\hline \multicolumn{8}{|l|}{ AMR } \\
\hline$/ \mathrm{p}^{\mathrm{h}} \Lambda /$ & .681 & $.515-.819$ & 2.104 & .035 & 3.8 & 65 & 65 \\
\hline$/ \mathrm{t}^{\mathrm{h}} \Lambda /$ & .585 & $.419-.738$ & .913 & .361 & 3.7 & 50 & 75 \\
\hline$/ \mathrm{k}^{\mathrm{h}} \Lambda /$ & .637 & $.471-.783$ & 1.552 & .121 & 3.3 & 45 & 80 \\
\hline$/ \Lambda_{\Lambda} /$ & .576 & $.410-.731$ & .828 & .408 & 3.6 & 45 & 70 \\
\hline$/ \mathrm{k} \wedge \mathrm{y} /$ & .599 & $.432-.750$ & 1.075 & .283 & 2.5 & 30 & 100 \\
\hline \multicolumn{8}{|l|}{ SMR } \\
\hline$/ p^{h} \Lambda t^{h} \Lambda k^{h} \Lambda /$ & .626 & $.459-.774$ & 1.415 & .157 & 1.2 & 40 & 80 \\
\hline
\end{tabular}

Cuttoff values were determined using Youden's index.

SMST-C=Speech Mechanism Screening Test for Children; DKK= diadochokinesis; $A U C=$ area under curve; $\mathrm{Cl}=$ confidence interval; $A M R=$ alternative motion rate; $S M R=$ sequential motion rate.

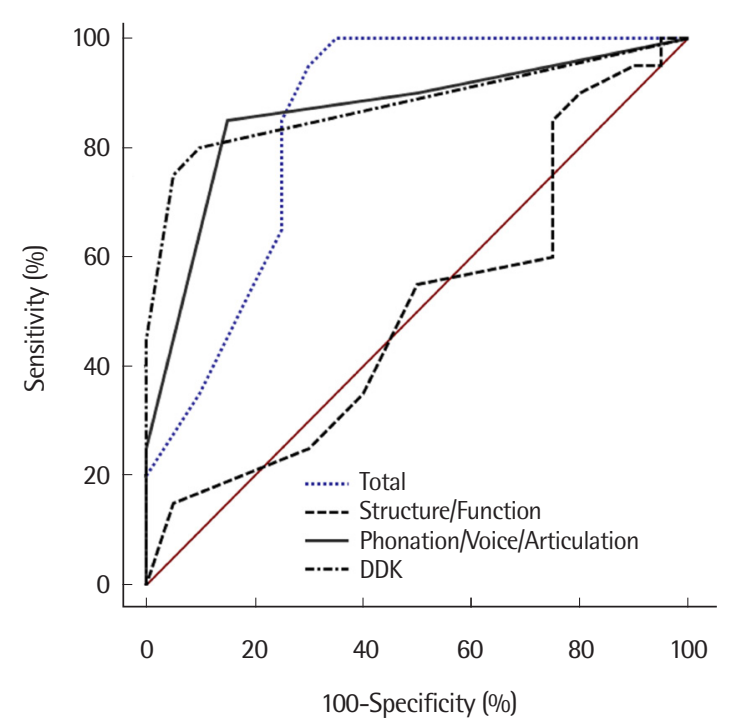

Figure 2. Receiver operating characteristic curve of total, structure/function, phonation/voice/articulation, and diadochokinesis (DDK) scores of Speech Mechanism Screening Test for Children.

는 각 $.846, .506, .864, .879$ 로 '조음교대운동' 점수가 가장 높았다. /퍼/, /터/, /커/, /러/, /겅/의 AMR과 /퍼터커/SMR의 AUC는 각 .681, $.585, .637, .576, .599 .626$ 이었다.

말소리장애 유무를 변별하는 절단점을 살펴보면, ‘총점수’는 93 점으로 이 때의 민감도가 $95 \%$, 특이도가 $70 \%$ 였다. '조음기관 구조. 기능은 절단점이 55 점으로 민감도와 특이도가 각 $60 \%$ 와 $25 \%$ 였고, '발성·음성·조음선별'은 12점으로 민감도가 $85 \%$, 특이도가 $85 \%$ 였 으며, '조음교대운동'은 23점으로 민감도와 특이도가 각 $80 \%$ 와 $90 \%$ 로 나타났다. 또한 /퍼/, /터/, /커/, /러/, /겅/의 AMR과 /퍼터커/의

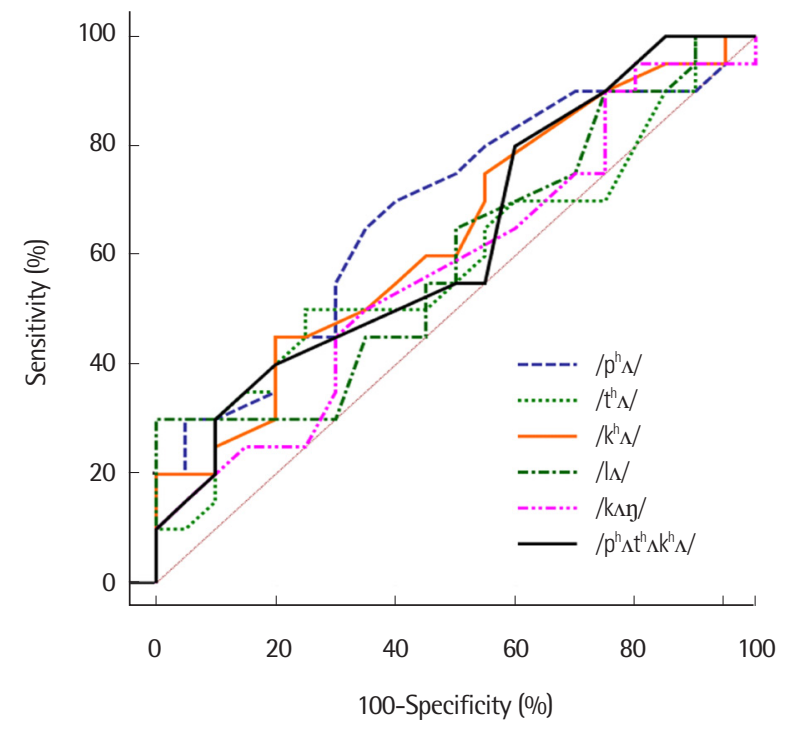

Figure 3. Receiver operating characteristic curve of alternative motion rate and sequential motion rate.

$\mathrm{SMR}$ 의 절단점(음절/초)은 각 $3.8,3.7,3.3,3.6,2.5,1.2$ 로 민감도와 특이도의 분포는 각 $30 \%-65 \%$ 와 $65 \%-100 \%$ 였다.

\section{논의 및 결론}

SMST-C가 개발되기 전에 말산출 기전의 구조와 기능을 평가하 기 위해 사용된 표준화 선별검사로는 Oral Speech Mechanisms Screening Examination-third edition (OSMSE-3; St. Louis \& Ruscello, 2000)과 Screening Test for Developmental Apraxia of Speech- 
second edition (STDAS-2; Blakeley, 2001) 그리고 성인용 SMST (Shin, Kim, Lee, \& Lee, 2008)가 있다. OSMSE-3는 5-78세까지 평 가가 가능하며, 구강 구조(전체 항목의 50\%)와 비구어 구강 운동 기능(전체 항목의 $42 \%$ ), 그리고 말운동 기능(전체 항목의 $8 \%$ )을 평 가하는 항목들로 구성된다. STDAS-2는 4-12세 아동의 말운동 기 능에만 초점을 맞추어 표현언어 차이, 운율, 구어 순서 및 조음의 항 목으로만 구성되어 있고, 조음기관의 구조나 기능을 평가하는 항 목은 없다(McCauley \& Strand, 2008). 국내에서 개발된 SMST와 SMST-C는 앞에서 언급한 바와 같이 음운능력을 선별하는 항목과 조음기관의 구조와 기능과 함께 말운동 기능을 평가하는 항목으 로 구성되어 있어 OSMSE-3와 매우 유사하다. OSMSE-3과 SMST$\mathrm{C}$ 를 비교해보면, OSMSE-3은 조음기관의 외관상 관찰되는 구조와 이들의 기능을 평가하는 항목을 정상과 비정상으로만 구분하고, $\mathrm{DDK}$ 속도와 이를 수행하는 동안의 리듬과 '조음정확성'을 별도로 기록한다. 반면, SMST-C는 구조와 기능 항목 및 DDK 속도 평가 시 ‘조음규칙성'과 ‘조음정확성’을 평가하여 점수화한다. 특히 음성 특성과 음운 능력을 선별하는 음성과 조음선별 항목들이 추가되 었고, 호흡과 후두의 협응 관계를 살펴보는 MPT와 말속도가 포함 되었으며, OSMSE-3에서 살펴보지 않은 조음기관의 기능과 말운 동 기능을 추가로 평가할 수 있다. 그리고 SMST-C에서는 각 항목 들의 점수체계를 정상, 약간 비정상, 심각한 비정상으로 좀 더 세분 화함으로써 각 조음기관의 이상 여부뿐 아니라 중증도까지 살펴볼 수 있어 말산출 기전의 이상 여부를 선별하는데 있어 좀 더 유용하 게사용될 수 있다.

본 연구는 최근 개발된 SMST-C가 원인이 명확하지 않은 말소리 장애 아동과 연령 및 성별을 일치시킨 일반아동 간 조음기관 구조 와 기능 및 말운동 능력의 차이를 변별할 수 있는지를 살펴보고자 하였다. 이를 위해 3-12세의 말소리장애로 진단받은 아동 20명과 일 반아동 20 명을 대상으로 SMST-C의 총점수와 이를 구성하는 세 하 위영역의 점수 및 $\mathrm{DDK}$ 속도를 측정하여 두 집단 간의 차이를 비교 하고 ROC 곡선 분석을 이용해 집단 간 변별 가능성을 살펴보았다.

SMST-C의 총점수는 말소리장애 아동이 일반아동에 비해 유의 하게 낮았는데, 이는 총점수를 구성하는 세 하위영역('조음기관 구 조·기능', '발성·음성·조음선별', ‘조음교대운동') 중 두 집단 간에 유의한 차이를 보인 ‘발성·음성·조음선별'의 ‘조음선별' 점수와 ‘조 음교대운동' 점수에 의한 영향이다. 두 집단 모두 신체적, 감각적, 정 서적, 행동적, 인지적 그리고 언어적인 문제가 없는 정상 범주에 속 하는 아동으로만 구성되었기 때문에 ‘조음기관 구조.기능'과 ‘음성' 은 총점수의 집단 간 차이에 영향을 미치지 못했다. 즉 순수 말소리 장애는 말소리를 산출하는 조음기관의 기질적 병변이나 그 기능의
이상에 의한 것이 아님을 SMST-C를 통해 재확인할 수 있었다. 특 히 조음선별 평가에서 그림을 통해 제시된 단어들의 어두초성에서 말소리장애 아동은 3명을 제외한 모든 아동에서 왜곡(2명)과 대치/ 생략(15명)이 나타난 반면, 일반아동은 3명에서만 왜곡이 나타났 다. 이는 SMST-C의 그림카드에서 제시하는 단어들이 말소리장애 아동을 변별하기 위한 선별적 검사로 사용될 수 있음을 시사한다. 다만, U-TAP에서 자음정확도가 -1 SD 이상인 정상 범주에 포함된 일반아동 중에서 SMST-C의 '조음선별'에서 왜곡을 보인 아동들 은 U-TAP에서 제시한 그림이나 문장에서는 말소리장애로 분류되 지 않았지만 SMST-C의 일부 단어의 어두초성에서 조음오류를 보 여 추후 말소리 관련 심화검사를 추가적으로 실시할 필요성이 제 기된다. 또한 $\mathrm{DDK}$ 속도를 측정하는 과정에서 조음의 규칙성과 정 확성을 평가하였는데, 말소리장애 아동이 불규칙적하고 부정확하 게 $\mathrm{DDK}$ 를 산출한 경우가 많아 조음의 규칙정과 정확성을 보는 '조 음교대운동' 영역이 말소리장애 아동을 일반아동으로부터 변별하 는데 유용함을 알 수 있다. 4-6세 말소리장애 아동의 DDK 정확성 과 일관성(consistency)을 살펴본 선행연구에서도 말소리장애 아 동이 일반아동에 비해 말산출이 정확하지 않고 일관성이 결여된다 고 하였다(Keske-Soares, Uberti, Gubiani, Ceron, \& Pagliarin, 2018). 이러한 결과들을 종합해 볼 때 SMST-C의 총점수와 총점수 를 구성하는 하위영역 점수가 말소리장애 아동을 일반아동으로부 터 변별할 수 있다는 가능성을 보여준다.

일부 연구자들에 의하면 말소리장애 아동은 정상 발달 아동에 비해 구강운동, 소근육운동, 대근육운동 능력이 저하되어 있다고 한다(Cermak et al., 1986; Farquharson, 2015, Peter \& Stoel-Gammon, 2008; Redle et al., 2015; Towne, 1994). 특히 Redle 등(2015)은 말소리장애 아동이 손가락 두드림(finger tapping)을 수행할 때 이 들의 대뇌상태를 기능적 자기공명영상(fMRI)을 통해 관찰하였는 데, 원인이 불분명한 말소리장애 아동은 양측 소뇌 후반부의 이상 과 관련하여 소근육 운동 기능의 결함이 존재한다고 하였다. 즉 원 인을 모르는 말소리장애를 평가할 때에는 말운동 능력에 관여하는 대뇌의 구조나 기능의 이상이 존재할 수 있기 때문에 말산출에 관 여하는 근육과 운동과정을 반드시 살펴보아야 한다는 것이다(Bradford \& Dodd, 1996). 말산출은 호흡, 발성, 조음 및 공명기관 그리고 이들 간 협응을 포함하여 이들을 조정하는 신경계의 복잡하고 정 교한 과정에 의해 이루어지는 과정이다. 따라서 미세한 신경계의 부조화나 이상 현상들이 원인을 명확하게 알 수 없는 말소리장애 를 유발할 수 있으므로 말운동 능력을 반드시 살펴보아야 한다.

말운동 능력을 평가하기 위한 과제로 DDK가 많이 사용된다. $\mathrm{DDK}$ 는 비단어 음절을 최대한 빠른 속도로 조음기관을 구성하고 
있는 근육들을 움직여 최대한의 운동속도를 측정한다. $\mathrm{DDK}$ 의 수 행능력이 느리거나 너무 빠른 경우 조음기관의 운동능력 또는 이 들 간의 협응 능력의 이상이 있음을 암시한다. 본 연구에서는 5 개 일음절의 $\mathrm{AMR}$ 과 1개 3음절의 SMR로 $\mathrm{DDK}$ 속도를 측정한 결과, $\mathrm{AMR}$ 에서 두 집단 간의 차이가 유의하게 나타났다. /퍼/와/커/에서 두 집단 간 $\mathrm{DDK}$ 평균값의 차이가 가장 크게 나타난 것을 포함하 여 모든 음절에서 말소리장애 아동이 일반아동에 비해 평균값이 전반적으로 낮았다. 말소리장애 아동과 일반아동의 DDK 속도를 비교한 선행연구를 살펴보면, 모든 조음위치의 파열음을 포함한 일음절의 AMR과 SMR에서 두 집단 간에 유의한 차이를 보였거나 (Ha, 2000; McNutt, 1977; Ourne, 1994; Toonen, Maassen, Gabreels, \& Schreuder, 1999; Wertzner, Pagan-Neves, Alves, \& Barrozo, 2013; Yoss \& Darley, 1974), /d//와 같은 치조음을 제외한 다 른 조음위치의 $\mathrm{AMR}$ 과 $\mathrm{SMR}$ 에서 집단 간 차이가 있거나(Dwor$\mathrm{kin}, 1978)$ 모든 조음위치의 $\mathrm{AMR}$ 과 SMR이 집단 간에 차이가 없 는 경우(Dworkin \& Culatta, 1985) 등 다양한 연구결과들이 있다. 이렇게 연구 간에 다른 결과가 나타난 것은 조음장애 중증도, 대상 자의 연령 또는 사용된 모음 등의 차이에서 기인된 것일 수 있다. 그 럼에도 불구하고 말소리장애 아동의 DDK 속도는 일반아동에 비 해 느리다는 것은 일반적으로 알려져 있다(Prathanee, Thanaviratananich, \& Pongjanyakul, 2003). 본 연구에서도 특히 입술과 연 구개를 사용하여 반복 조음하거나 여러 조음위치를 바꾸면서 반복 조음할 때는 말소리장애 아동이 일반아동에 비해 그 운동능력이 더 많이 감소하였다. 즉 말소리장애 아동은 일음절이나 다음절을 반복할 때 조음의 위치에 상관없이 일반아동에 비해 조음기관을 반복적으로 빠르게 움직이는 운동능력이 다소 감소해 있음을 알 수 있다. 입술, 혀, 연구개 등 조음기관의 움직임에 관여하는 신경계 의 미성숙과 약한 근력은 말소리 산출의 오류와 높은 상관성을 갖 는다(Potter, Nievergelt, \& VanDam, 2019; Towne, 1994; Yoss \& Darley, 1974). 말소리장애 분류체계(Speech Disorders Classification System, SDCS; Shriberg et al., 1994; Shriberg \& Kwaitkowski, 1994; Shiberg et al., 2010, 2017)에 따른 말소리지연(speech delay)이 나 말소리오류(speech error)를 보이는 말소리장애 아동은 신경계 영향에 의한 말운동장애(motor speech disorder) 아동과 달리 혀의 근력이 일반아동과 차이가 없다고 한다(Potter et al., 2019). 즉 언어 적인 요소가 관여하는 말소리장애 아동에 비해 말운동과 관련된 말소리장애 아동에서 말운동 능력이 더 감소할 수 있다는 것이다.

$\mathrm{AMR}$ 의 조음위치에 따라 두 집단의 차이를 비교한 결과, 말소리 장애 아동과 일반아동 모두 /터/가 가장 빠른 속도를 보이고 그 다 음으로 /퍼/가 빨랐으며, /커/와 /겅/이 가장 느린 속도를 보였다. 이
는 두 집단 모두 조음기관 중에서 혀와 입술이 가장 많이 사용되고 용이하게 움직일 수 있으므로 조음점이 구강 뒤쪽에 있는 경구개 나 연구개에 비해 빠른 속도로 반복운동이 가능함을 나타낸다. 또 한 구강음과 비강음을 반복적으로 산출하기 위한 연구개의 움직임 은 가장 느리다는 것을 나타낸다(Choe \& Han, 1998; Kim et al., 2018; Prathanee et al., 2003; Shin et al., 2008), 다만, 일반아동은 /겅/이/퍼/, /터/, /커/의 각 세 음절과 통계적으로 유의한 차이가 있 었던 반면, 말소리장애 아동은 /겅/과 /터/ 간에만 유의한 차이가 나타나 말소리장애 아동은 음소의 위치에 따른 AMR의 차이가 크 지 않음을 알 수 있다.

SMST-C가 말소리장애를 변별할 수 있는지를 살펴보기 위해 실 시한 ROC 곡선 분석 결과, '총점수, '발성·음성·조음선별', ‘조음교 대운동'의 AUC가 .80 이상으로 Muller 등(2005)과 Simunci (2009) 의 기준 $(0.9-1.0=$ excellent, $0.8-0.9=$ very good, $0.7-0.8=$ good, 0.6-0.7 = sufficient, $0.5-0.6=$ bad, $<0.5=$ not useful)에 따라 말소 리장애 변별 가능성이 높은 것으로 나타났다. 그 중에서도 말소리 장애를 변별할 가능성이 가장 높은 변수는 $\mathrm{DDK}$ 속도 측정 시 평 가되는 '조음교대운동' $(\mathrm{AUC}=879)$ 이었고, 그 다음으로 총점수 (AUC=.846)와 ‘발성·음성·조음선별’ $(\mathrm{AUC}=.864)$ 의 순이었다. $\mathrm{AMR}$ 과 SMR의 AUC는 .58-68로 분포되어 있어 보통 정도의 변별 가능성을 보인다. 또한 앞에서 언급한 바와 같이 '조음교대운동', 총 점수 및 '발성·음성·조음선별'의 '조음선별'은 말소리장애 아동이 일반아동에 비해 유의하게 낮은 점수를 보여 이 영역들은 말소리 장애를 감별 진단하는 매개변수로 사용될 수 있음을 제시한다. $\mathrm{ROC}$ 곡선 분석에서 민감도는 장애군을 비장애군으로부터 정확하 게 변별하는 비율을 의미하고, 특이도는 비장애군을 장애군으로 부터 변별하는 비율을 말한다(Lee, $\mathrm{Ha}, \& \mathrm{Oh}, 2008)$. 장애군과 비 장애군을 변별하는 절단점은 일반적으로 민감도와 특이도의 합산 이 가장 높은 지점이다(Muller et al., 2005). 본 연구의 ROC 곡선 분 석에서 총점수(0-100점)가 93점일 때 민감도(95\%)와 특이도(70\%) 의 합산이 가장 높아 두 집단을 잘 변별할 수 있는 절단점으로 나타 났고, '발성·음성·조음선별(0-16점)'은 12점, '조음교대운동(0-24 점)'은 23점일 때 민감도(각 $85 \%$ 와 $80 \%$ )와 특이도(각 $85 \%$ 와 90\%) 의 합산이 가장 높은 절단점으로 나타났다. 이러한 각 하위영역별 절단점은 추후 말소리장애 아동을 변별하기 위한 참조값으로 사용 될 수 있을 것이다.

본 연구를 통해 SMST-C가 아동에서 보이는 말소리장애를 변별 하는 선별검사 도구로서 유용하게 사용될 수 있다는 가능성을 보 여준다. 이에 말소리장애로 의심되는 학령전기 아동을 평가할 때 SMST-C에서 조음기관의 구조나 기능에는 이상이 없으나 비구어 
음절 반복 평가에서 조음의 규칙성과 정확성의 이상이 보이며 어 두초성의 조음오류가 있다면 순수 말소리장애로 의심해 볼 필요가 있다. 그리고 이들을 보다 정확하게 진단하기 위해 심화검사를 실 시하여야할 것이다.

연구의 결과를 바탕으로 본 연구의 제한점과 제언은 다음과 같다.

첫째, 본 연구에 포함된 아동의 연령이 3-6세로 DDK 속도의 평 균값의 범위가 넓게 나타났다. 일반적으로 DDK 속도는 연령이 증 가할수록 초당 음절수가 감소하여 점점 빨라진다고 알려져 있다 (Choe \& Han, 1998; Kim et al., 2018). 이에 추후 말소리장애 아동 의 DDK 속도를 측정하여 일반아동과 비교하기 위해서는 연령대 를 보다 세분화하여 살펴보아야 하며, $\mathrm{DDK}$ 를 측정할 때 함께 살펴 보는 조음의 규칙성과 정확성 또한 세분화된 연령대에 따라 살펴 볼 필요가 있다.

둘째, 본 연구에서 $\mathrm{DDK}$ 속도를 측정하기 위해 2 회 반복 측정한 값들의 평균을 사용하였다. SMST-C를 평가하는 매뉴얼에 의하면 3 회 반복 측정치의 평균을 산출하여 $\mathrm{AMR}$ 과 $\mathrm{SMR}$ 의 초당 음절수 를 산출하여야 한다. Diepeveen, van Haaften, Terband, de Swart 및 Maassen (2019)의 연구에서 2-7세 아동을 대상으로 1음절, 2음 절 및 3음절의 비구어 단어를 빠르게 조음하는 횟수를 여러 번 반 복 측정하였을 때 $\mathrm{DDK}$ 의 반복 속도가 빨라지는 경우는 전체 대상 자의 $20 \%$ 이하로 나타났다. 즉 반복 횟수가 많아진다고 해서 반복 속도가 향상되는 것은 아니며, 2 회 정도가 임상적으로 가장 합리적 이라고 하였다. 이에 본 연구에서도 SMST-C 매뉴얼과 DDK 속도 측정과 관련된 연구에서 일반적으로 사용하는 3 회 반복 측정값 대 신 2회 반복 측정된 평균을 사용하였다.

또한 $\mathrm{AMR}$ 과 $\mathrm{SMR}$ 의 정확한 측정치를 얻기 위해서는 다수의 반 복에 의해 산출된 정확한 값을 구하는 것도 중요하지만 SMST-C가 선별검사라는 특성상 말산출 체계의 이상 여부를 감별하고 빠른 시간 안에 검사가 이루어지는 것이 중요하다. 이에 임상에서 SMST$\mathrm{C}$ 평가를 위한 $\mathrm{DDK}$ 속도를 측정할 때에는 아동에게 1-2회 정도의 $\mathrm{DDK}$ 를 실시하게 함으로써 선별검사를 보다 신속하고 용이하게 실 시하는 것도 필요하다.

셋째, 본 연구에서는 SDCS의 말소리장애 분류체계(Shriberg et al., 2017)나 Dodd의 진단 모델(Dodd's Model for Differential Diagnosis; Dodd, 2014) 등에 따른 말소리장애 유형을 구분하지 않고 단순히 조음기관의 구조적인 이상이 없는 순수 말소리장애 아동만 을 대상으로 SMST-C를 실시하였다. 추후에는 이러한 말소리장애 분류체계에 따라 구고적 이상이나 원인이 분명한 말소리장애 아동 들을 포함하여 SMST-C가 이들도 함께 선별할 수 있는지를 평가해 볼 필요가 있다.
조기선별을 통한 의사소통장애의 조기중재는 아동의 발달에 중 대한 영향을 미친다(Kim, 2014). 본 연구의 결과는 말산출 기전의 이상 유무를 선별하기 위해 개발된 SMST-C가 말소리장애 아동을 일반아동으로부터 변별하는데 사용될 수 있는 가능성을 보여준 다. 임상에서 의사소통장애 아동을 평가할 때 단순히 언어적 측면 만을 평가하는 것이 아니라 말산출 기전과 관련된 기관의 구조나 기능 그리고 말운동성을 평가하는 SMST-C와 같은 검사를 사용함 으로써 말소리산출 기전의 병리적 이상이 있는 아동을 조기에 선 별하고 조기에 중재를 제공하는 것이 중요할 것이다.

\section{REFERENCES}

Blakeley, R. W. (2001). STDAS-2: Screening Test for Developmental Apraxia of Speech. Austin, TX: Pro-Ed.

Bradford, A., \& Dodd, B. (1996). Do all speech-disordered children have motor deficits? Clinical Linguistics \& Phonetics, 10(2), 77-101.

Cermak, S. A., Ward, E. A., \& Ward, L. M. (1986). The relationship between articulation disorders and motor coordination in children. American Journal of Occupational Therapy, 40(8), 546-550.

Choe, J., \& Han, J. S. (1998). Diadochokinetic rate of normal children and adults: a preliminary study. Korean Journal of Communication \& Disorders, 3(1), 183-194.

Diepeveen, S., van Haaften, L., Terband, H., de Swart, B., \& Maassen, B. (2019). A standardized protocol for maximum repetition rate assessment in children. Folia Phoniatrica et Logopaedica, 71(5-6), 238-250.

Dodd, B. (2014). Differential diagnosis of pediatric speech sound disorder. Current Developmental Disorders Reports, 1(3), 189-196.

Dworkin, J. P. (1978). Protrusive lingual force and lingual diadochokinetic rates: a comparative analysis between normal and lisping speakers. Language, Speech, and Hearing Services in Schools, 9(1), 8-16.

Dworkin, J. P., \& Culatta, R. A. (1985). Oral structural and neuromuscular characteristics in children with normal and disordered articulation. Journal of Speech and Hearing Disorders, 50(2), 150-156.

Farquharson, K. (2015). Language or motor: reviewing categorical etiologies of speech sound disorders. Frontiers in Psychology, 6, 1708.

Grigos, M. I. (2016). Speech sound disorders: what's motor got to do with it? Perspectives of the ASHA Special Interest Groups, 1(1), 75-87.

Ha, J. W. (2000). Diadochokinetic rate and variability in children with normal and disordered articulation (Master's thesis). Ewha Womans University, Seoul, Korea. 
Jessup, B., Ward, E., Cahill, L., \& Keating, D. (2008). Prevalence of speech and/or language impairment in preparatory students in northern Tasmania. International Journal of Speech-Language Pathology, 10(5), 364-377.

Keske-Soares, M., Uberti, L. B., Gubiani, M. B., Ceron, M. I., \& Pagliarin, K. C. (2018). Performance of children with speech sound disorders in the dynamic evaluation of motor speech skills. CoDAS, 30(2), e20170037.

Kim, J. O., \& Lee, C. Y. (2018). Comparison of speech mechanism between children with and without cerebral palsy. Journal of Speech-Language \& Hearing Disorders, 27(2), 147-157.

Kim, J., Shin, M., \& Song, Y. K. (2018). Speech mechanism screening test for children: an evaluation of performance in 3-to 12-year-old normal developing children. Communication Sciences \& Disorders, 23(1), 180-197.

Kim, M. J., \& Pae, S. Y. (2005). The percentage of consonants correct and the ages of consonantal acquisition for 'Korean-Test of Articulation for Children (K-TAC)'. Speech Sciences, 12(2), 139-149.

Kim, S. J., \& Shin, J. Y. (2015). Speech sound disorders. Seoul: Sigmapress.

Kim, S. J., \& Yoo, H. J. (2014). Development of sentence repetition screening test for 5 to 6-year-olds. Proceedings of 2014 Annual conference of the Korean Academy of Speech-Language Pathology and Audiology, 43-46.

Kim, S. J., Kim, M. J., Ha, J., \& Ha, S. H. (2014). Status of speech sound disorders in clinics. Proceedings of 2014 Fall Conference on Korean Society of Speech Sciences, 153-154.

Kim, Y. S., \& Kim, J. O. (2016). A preliminary study to develop a Speech Mechanism Screening Test for preschool children. Journal of Speech-Language \& Hearing Disorders, 25(25), 105-123.

Kim, Y. T. (1995). A comparative study of the phonological processes between the normal and the articulation-disordered children. Korean Journal of Special Education, 12, 211-235.

Kim, Y. T. (2014). Diagnosis and treatment of language disorders in children (2nd ed.). Seoul: Hakjisa.

Kim, Y. T., \& Shin, M. J. (2004). Urimal Test of Articulation and Phonology (U-TAP). Seoul: Hakjisa.

Kim, Y. T., Hong, G. H., Kim, K. H., Jang, H. S., \& Lee, J. Y. (2009). Receptive \& expressive vocabulary test (REVT). Seoul: Seoul Community Rehabilitation Center.

Ko, Y. K., Seo, E. Y., Oh, G., \& Kim, S. (2017). Comorbidity of language impairment according to gender, age, and severity in children with speech sound disorders. Journal of Speech-Language \& Hearing Disorders, 26(4), 99-109.

Law, J., Boyle, J., Harris, F., Harkness, A., \& Nye, C. (2000). Prevalence and natural history of primary speech and language delay: findings from a systematic review of the literature. International Journal of Language and Communication Disorders, 35(2), 165-188.

Lee, S. J., Ha, E. H., \& Oh, K. J. (2008). Discriminating of ADHD children with K-CBCL subscales: a receiver operating characteristic (ROC) analysis. Korean Journal of Clinical Psychology, 27(1), 191-207.

Lewis, B. A., Avrich, A. A., Freebairn, L. A., Hansen, A. J., Sucheston, L. E., Kuo, I., ... \& Stein, C. M. (2011). Literacy outcomes of children with early childhood speech sound disorders: impact of endophenotypes. Journal of Speech, Language, and Hearing Research, 54(6), 1628-1643.

McCauley, R. J., \& Strand, E. A. (2008). A review of standardized tests of nonverbal oral and speech motor performance in children. American Journal of Speech-Language Pathology, 17(1), 81-91.

McKinnon, D. H., McLeod, S., \& Reilly, S. (2007). The prevalence of stuttering, voice, and speech-sound disorders in primary school students in Australia. Language, Speech, and Hearing Services in Schools, 38(1), 5-15.

McLeod, S., \& Harrison, L. J. (2009). Epidemiology of speech and language impairment in a nationally representative sample of 4-to 5-year-old children. Journal of Speech, Language, and Hearing Research, 52(5), 1213-1229.

McNutt, J. C. (1977). Oral sensory and motor behaviors of children with /s/ or /r/ misarticulations. Journal of Speech and Hearing Research, 20(4), 694703.

Muller, M. P., Tomlinson, G., Marrie, T. J., Tang, P., McGeer, A., Low, D. E., ... \& Gold, W. L. (2005). Can routine laboratory tests discriminate between severe acute respiratory syndrome and other causes of community-acquired pneumonia? Clinical Infectious Diseases, 40(8), 1079-1086.

Newmeyer, A. J., Grether, S., Grasha, C., White, J., Akers, R., Aylward, C., ... \& Degrauw, T. (2007). Fine motor function and oral-motor imitation skills in preschool-age children with speech-sound disorders. Clinical Pediatrics, 46(7), 604-611.

Ourne, R. I. (1994). Effect of mandibular stabilization on the diadochokinetic performance of children with phonological disorders. Journal of Phonetics, $22(3), 317-332$.

Peter, B., \& Stoel-Gammon, C. (2008). Central timing deficits in subtypes of primary speech disorders. Clinical Linguistics \& Phonetics, 22(3), 171-198.

Potter, N. L., Nievergelt, Y., \& VanDam, M. (2019). Tongue strength in children with and without speech sound disorders. American Journal of SpeechLanguage Pathology, 28(2), 612-622.

Prathanee, B., Thanaviratananich, S., \& Pongjanyakul, A. (2003). Oral diadochokinetic rates for normal Thai children. International Journal of Lan- 
guage \& Communication Disorders, 38(4), 417-428.

Redle, E., Vannest, J., Maloney, T., Tsevat, R. K., Eikenberry, S., Lewis, B., ... \& Holland, S. K. (2015). Functional MRI evidence for fine motor praxis dysfunction in children with persistent speech disorders. Brain Research, 1597, 47-56.

Shin, M. J., Kim, J. O., Lee, S. B., \& Lee, S. Y. (2008). A preliminary study of developing Korean Oro-motor Mechanism Screening Examination (KOMSE) in normal adults. Speech Sciences, 15(4), 171-188.

Shriberg, L. D., \& Kwiatkowski, J. (1994). Developmental phonological disorders, I: A clinical profile. Journal of Speech, Language, and Hearing Research, $37(5), 1100-1126$.

Shriberg, L. D., Fourakis, M., Hall, S. D., Karlsson, H. B., Lohmeier, H. L., McSweeny, J. L., ... \& Wilson, D. L. (2010). Extensions to the speech disorders classification system (SDCS). Clinical Linguistics \& Phonetics, 24(10), 795-824.

Shriberg, L. D., Gruber, F. A., \& Kwiatkowski, J. (1994). Developmental phonological disorders, III: Long-term speech-sound normalization. Journal of Speech, Language, and Hearing Research, 37(5), 1151-1177.

Shriberg, L. D., Strand, E. A., Fourakis, M., Jakielski, K. J., Hall, S. D., Karlsson, H. B., ... \& Wilson, D. L. (2017). A diagnostic marker to discriminate childhood apraxia of speech from speech delay, I. Development and description of the pause marker. Journal of Speech, Language, and Hearing Research, 60(4), S1096-S1117.

Simunci, A. M. (2009). Diagnostic accuracy-part 1, basic concepts: sensitivity and specificity, ROC analysis, STARD statement. Retrieved from https:// acutecaretesting.org

St. Louis, K. O., \& Ruscello, D. M. (2000). Oral speech mechanism screening examination. Austin, TX: Pro-Ed.

Toonen, G., Maassen, B., Gabreels, F., \& Schreuder, R. (1999). Validity of maximum performance tasks to diagnose motor speech disorders in children. Clinical Linguistics \& Phonetics, 13(1), 1-23.

Towne, R. L. (1994). Effect of mandibular stabilization on the diadochokinetic performance of children with phonological disorder. Journal of Phonetics, 22(3), 317-332.

Vick, J. C., Campbell, T. F., Shriberg, L. D., Green, J. R., Truemper, K., Rusiewicz, H. L., \& Moore, C. A. (2014). Data-driven subclassification of speech sound disorders in preschool children. Journal of Speech, Language, and Hearing Research, 57(6), 2033-2050.

Waring, R., \& Knight, R. (2013). How should children with speech sound disorders be classified? A review and critical evaluation of current classification systems. International Journal of Language \& Communication Disorders, 48(1), 25-40.

Wertzner, H. F., Pagan-Neves, L. D. O., Alves, R. R., \& Barrozo, T. F. (2013). Implications of diadochokinesia in children with speech sound disorder. CoDAS, 25(1), 52-58.

Yoss, K. A., \& Darley, F. L. (1974). Developmental apraxia of speech in children with defective articulation. Journal of Speech and Hearing Research, 17(3), 399-416. 
Appendix 1. Speech Mechanism Screening Test for Children (SMST-C)의 구 성요소 및 점수체계

\begin{tabular}{|c|c|c|}
\hline \multirow{2}{*}{ 영역 } & \multicolumn{2}{|l|}{ SMST-C } \\
\hline & 항목 & 점수 \\
\hline \multirow[t]{8}{*}{ 조음기관 구조·기능 } & 얼굴(3) & 구조: 14항목(28점) \\
\hline & 입술(5) & 기능: 16항목(32점) \\
\hline & 혀(8) & \\
\hline & 턱과 치아(4) & \\
\hline & 경구개 및 연구개(6) & \\
\hline & 인두(1) & \\
\hline & 호흡(3) & \\
\hline & 소계 & 60점 \\
\hline 발성·음성·조음선별 & $\begin{array}{l}\text { 음도, 음강, 음색(과제: MPT, } \\
\text { 자발화, 그림카드/읽기카드) }\end{array}$ & 3항목(12점) \\
\hline 발성·음성 & 최대연장발성(MPT) & \\
\hline 조음선별 & $\begin{array}{l}\text { 자음정확성 } \\
\text { 학령전기: 어두초성자음 } \\
\text { 학령기: ㄹ, , ㅈ }\end{array}$ & 1항목(4점) \\
\hline \multirow[t]{2}{*}{ 말속도 } & 말속도(과제: 읽기카드) & \\
\hline & 소계 & 16점 \\
\hline \multirow[t]{5}{*}{ 조음교대운동 } & 조음규칙성 & 6항목(12점) \\
\hline & 조음정확성 & 6항목(12점) \\
\hline & AMR: 퍼, 터, 커, 러, 겅 & \\
\hline & SMR: 퍼터커 & \\
\hline & 소계 & 24점 \\
\hline 총점수 & & 100점 \\
\hline
\end{tabular}




\section{국문초록}

\section{아동용 조음기관 구조·기능 선별검사(SMST-C)의 말소리장애 아동 변별력: ROC 곡선 분석 김재옥}

강남대학교 교육대학원 언어치료교육전공

배경 및 목적: 본 연구는 아동용 조음기관 구조·기능 선별검사(Speech Mechanism Screening Test for Children (SMST-C)를 이용하여 말소리장애 아동과 일반아동을 변별할 수 있는지 살펴보고자 하였다. 방법: 대상자는 3-12세의 말소리장애 아동 20 명과 일반아동 20 명이었다. 각 집단은 13 명의 남아와 7 명의 여아로 구성되었고, 평균 연령은 4.75 세였다. 대상 아동에게 SMST-C의 '조음기관 구조.기능, '발성·음성·조음선별' '조음교대운동'을 평가하여 총점수를 산출하였고, /퍼/, /터/, /커/, /러/, /겅/의 교대운동속도와/퍼터커/의 일련운 동속도인 조음교대운동속도(diadochokinetic [DKK] rate)를 평가하여 두 집단 간의 차이를 비교하였다. 또한 수신자 조작 특성(receiver operating characteristics, ROC) 곡선 분석을 실시하여 두 집단을 변별할 수 있는 절단점을 산출하였다. 결과: 말소리장애 아동은 일 반아동에 비해 총점수, ‘조음선별' 점수, ‘조음교대운동’ 점수가 유의하게 낮았다. 또한 말소리장애 아동은 /퍼/, /커/, /겅/, /퍼터커/의 $\mathrm{DDK}$ 속도도 유의하게 느렸다. 그러나 ‘조음기관 구조.기능' 점수와 ‘음성' 점수는 집단 간에 차이가 없었다. $\mathrm{ROC}$ 곡선 분석 결과, ‘조음 교대운동' 점수(area under curve $[\mathrm{AUC}]=.879$ ), '발성·음성·조음선별' 점수(AUC=.864), 그리고 총점수(AUC=.846)가 말소리장애를 변별하는 진단적 유용성이 높게 나타났다. 논의 및 결론: 본 연구는 말소리장애 아동에 대한 SMST-C의 양적 자료를 제공하였다. SMST-C는 말소리장애 아동의 말소리 산출 기전을 선별하는데 도움이 되며, 임상에서 말산출 기전의 이상이 있는 아동을 변별하는데 유용한 도구로 사용될 수 있을 것이다.

핵심어: 아동용 조음기관 구조 · 기능 선별검사, 말소리장애, 조음교대운동속도

본 연구는 2016학년도 2차 강남대학교 교내연구비 지원에 의해 수행되었으며, 2018년 11월 16일에 개최된 미국언어병리학회 학술대회에서 일 부 발표되었음.

\section{참고문헌}

고유경·서은영.오경아·김수진 (2017). 말소리장애아동의 성별, 연령별, 중증도에 따른 언어장애 동반비율. 언어치료연구, 26(4), 99-109. 김민정, 배소영(2005). 아동용 조음검사를 이용한 연령별 자음정확도와 우리말 자음의 습득연령. 음성과학, 12(2), 139-149.

김수진, 김민정, 하지완, 하승희(2014). 임상현장의 말소리장애 현황. 가을학술대회 자료집, 153-154.

김수진, 신지영(2015). 말소리장애. 서울: 시그마프레스.

김수진, 유하진(2014). 5, 6세 아동을 위한 따라말하기 선별검사의 개발. 2014년 한국언어청각임상학회 학술대회 발표논문집, 43-46.

김양선, 김재옥(2016). 아동용 조음기관 구조 및 기능 선별검사 제작을 위한 학령전기 아동 대상 예비조사. 언어치료연구, 25(3), 105-123.

김영태 (1995). 조음장애와 정상아의 음운변동 패턴에 관한 비교 연구. 특수교육논총, 12, 211-235.

김영태(2014). 아동언어장애의 진단 및 치료(제2판). 서울: 학지사.

김영태, 신문자(2004). 우리말 조음음운 평가(U-TAP). 서울: 학지사.

김영태, 홍경훈, 김경희, 장혜성, 이주연(2009). 수용·표현어휘력검사(REVT). 서울: 서울장애인종합복지관.

김재옥, 신문자, 송윤경(2018). 아동용 조음기관 구조 및 기능 선별검사: 3-12세 정상 발달 아동의 수행 특성 평가. Communication Sciences \& Disor-

ders, 23(1), 1-18.

김재옥, 이조영(2018). 뇌성마비 아동과 일반 아동의 말산출 하부 체계 구조 및 기능 비교. 언어치료연구, 27(2), 147-157.

신문자, 김재옥, 이수복,이소연(2008). 정상성인의 조음기관 구조 및 기능선별검사 제작을 위한 예비연구.음성과학, 15(4), 171-188.

이수진, 하은혜, 오경자(2008). ROC 분석을 통한 주의력결핍 과잉행동장애 아동의 변별. 한국심리학회지: 임상, 27(1), 191-207. 
최정윤, 한진순(1998). 정상아동과 성인의 교대운동속도에 관한 연구. 언어청각장애연구, 3(1), 183-193.

하지완(2000). 기능적 조음장애아동과 정상아동의 교대운동속도 및 가변성 비교. 이화여자대학교 대학원 석사학위논문.

\section{ORCID}

김재옥(제1저자, 교신저자, https://orcid.org/0000-0002-6504-7294) 